\title{
PENGARUH PERILAKU INOVATIF TERHADAP KESUKSESAN KARIR MELALUI SELF-EFFICACY KARYAWAN PT BANK PEMBANGUNAN DAERAH JAWA TIMUR TBK KANTOR PUSAT SURABAYA
}

\author{
Candra Yulia Ningrum \\ Fakultas Ekonomi, Universitas Negeri Surabaya \\ e-mail: candrayulia768@gmail.com
}

\begin{abstract}
The research aims to determine and explain the effect of Innovative Behavior on Career Success through Employee Self-Efficacy of PT Bank Pembangunan Daerah Jawa Timur Tbk Head Office of Surabaya. This is a causal research with quantitative approach. The sample collecting technique is using purposive sampling with 89 respondent from all divisions in the company. The statistical analysis used is Partial Least Square (PLS) with the support of smartPLS software. The results of this research show that Innovative Behavior has positive and significant effect on Career Success. Innovative Behavior has positive and significant effect on Self-Efficacy. Self-Efficacy has positive and significant effect on Career Success. Self-efficacy not mediate the influence of innovative behavior on career success.
\end{abstract}

Keywords: innovative behavior, career success, self-efficacy

\section{PENDAHULUAN}

Dunia bisnis yang berkembang sangat pesat menuntut seluruh aspek dalam organisasi agar mampu bergerak dan berubah dengan cepat. Suatu organisasi atau perseorangan dituntut untuk mampu menyesuaikan diri serta memanfaatkan sumber daya yang ada secara maksimal agar dapat mengikuti perkembangan jaman sehingga mampu mencapai tujuan yang telah ditetapkan. Organisasi atau perseorangan yang mampu mencapai tujuan yang ditetapkan sering dikatakan berhasil atau sukses. Pada dunia kerja di Indonesia, dalam perjalanan karirnya seluruh karyawan selalu mengupayakan untuk mecapai level tertentu atas hasil dari usaha-usaha yang telah dilakukan untuk mendukung perkembangan karirnya.

Survei yang dilakukan oleh LinkedIn (2014) dengan responden 18.000 profesional dari 26 negara di dunia menunjukan bahwa Indonesia merupakan negara dengan tingkat kepuasan kerja tertinggi di di dunia. Dalam survei ini melibatkan 26 negara dengan total responden sebanyak lebih dari 18.000 profesional. Responden dari negara Indonesia yaitu sebanyak 580 profesional. Berdasarkan hasil survei profesional dari Indonesia memiliki tingkat kepuasan karir sebesar $84 \%$ dan mengatakan bahwa mereka telah puas dengan karirnya saat ini. Hasil tersebut lebih tinggi dari angka rata-rata kepuasan karir di dunia dan lebih tinggi dari beberapa negara yang juga merupakan responden dari survei, yaitu Swedia $83 \%$,
Norwegia 81\%, Hongkong 67\%, Italia 67\%, Jepang 65\% dan Turki 63\% (LinkedIn, 2014).

Zacher (2014) menjelaskan bahwa kesuksesan karir merupakan hasil positif individu dalam pekerjaannya yang mencakup keputusan karir, perilaku, dan pengalaman kerja. Peiperl et al. (2001) menyatakan bahwa penghasilan tinggi dan posisi tinggi tidak selalu terkait dengan keberhasilan pengembangan karir seseorang dan keberhasilan karir lebih mengarah kepada standar subjektif, seperti suasana kerja di antara rekan kerja atau kepuasan kerja secara bertahap. Tidak ada yang dapat menjamin promosi dan gaji dapat menjadikan karyawan merasa puas dengan kesuksesan karirnya (Hall, 2000). Dalam penelitian ini kesuksesan karir difokuskan pada kesuksesan karir subjektif.

Kesuksesan selalu dipengaruhi oleh beberapa faktor yang tidak pernah lepas di dalamnya. Adapun faktor yang dapat mempengaruhi kesuksesan karir adalah perilaku inovatif. Penelitian yang dilakukan oleh Aime et al. (2011) yang menunjukan bahwa perilaku inovatif memiliki pengaruh signifikan positif terhadap kesuksesan karir. Penelitian yang dilakukan oleh Seibert et al. (2001) juga menunjukan bahwa perilaku inovatif memiliki pengaruh signifikan positif terhadap kesuksesan karir.

Namun, hal berbeda diungkapkan oleh penelitian Azizah dan Ma'rifah (2017) pada 58 
responden di Kabupaten Kebumen yang menunjukan bahwa perilaku inovatif tidak memiliki pengaruh terhadap kesuksesan. Hal ini dikarenakan perilaku inovatif yang dimiliki masih rendah dan perlu dikelola dengan baik sehingga nantinya mampu berkontribusi terhadap kesuksesan mereka.

Selain berpengaruh terhadap kesuksesan karir, perilaku inovatif juga mampu menciptakan keyakinan individu dalam menghadapi tantangan yang ada. Oleh sebab itu, perilaku inovatif dibutuhkan untuk menciptakan self-efficacy pada karyawan. Didukung oleh penelitian Grosser et al. (2017) dan Runhaar et al. (2013) yang menunjukan bahwa perilaku inovatif berpengaruh terhadap selfefficacy scara positif. Namun Sura dan Hadi (2017) menunujukan hasil yang berbeda pada 20 penyiar radio di Surabaya yang menyatakan bahwa tidak ada hubungan antara perilaku inovatif dan selfefficacy.

Self-efficacy tidak hanya berkaitan dengan perilaku inovatif, tetapi juga sangat berpengaruh terhadap kesuksesan karir Brown et al. (2005). Hirschi dan Jaensch (2015) melalui penelitiannya menyatakan bahwa self-efficacy memiliki pengaruh positif pada kesuksesan karir. Hasil tersebut juga sama dengan penelitian Abele dan Spurk (2009) dan Chughtai (2018) yang menunjukan bahwa selfefficacy berpengaruh positif terhadap kesuksesan karir.

Penelitian ini dilakukan pada PT. Bank Pembangunan Daerah Jawa Timur Tbk. Kantor Pusat Surabaya yang beralamat di Jl. Basuki Rachmat No. 98-104 Surabaya. Perusahaan ini adalah sebuah perusahaan dalam bidang perbankan yang merupakan BUMD berada di Provinsi Jawa Timur.

Berdasarkan wawancara yang dilakukan di PT. Bank Pembangunan Daerah Jawa Timur Tbk. Kantor Pusat Surabaya dengan Kepala Pengembangan Produk dan Kebijakan pada penelitian terdahulu, mengatakan bahwa seluruh karyawan memiliki tuntutan untuk mencari nasabah setiap tahunya, namun banyak karyawan di seluruh divisi perusahaan yang tidak mencapai target tersebut. Untuk mendapatkan manajemen karir, bonus dan insentif seharusnya karyawan mampu memperoleh nilai diatas 3 dari skala 1-5 yang telah ditetapkan oleh perusahaan. Ini menunjukan tingkat self-efficacy karawyan yang masih rendah karena tidak mampu menghadapi tuntutan pekerjaan yang diberikan. Hasil wawancara tersebut sejalan dengan apa yang disampaikan oleh Junior Analyst yang menerangkan bahwa karyawan memang masih memiliki kemandirian yang lemah dalam mencari nasabah untuk memenuhi target yang ditetapkan oleh perusahaan. Padahal seharusnya pencapaian tersebut merupakan tanggung jawab dari masingmasing karyawan. Kemampuan menghadapi tuntutan tugas ini dinilai masih lemah dikarenakan self-efficacy yang dimiliki karyawan masih rendah.

Namun, dilihat dari sisi subjektif karyawan dinilai puas dengan karirnya karena rendahnya angka karyawan yang ingin keluar dari perusahaan. Berdasarkan hal tersebut dapat dikatakan bahwa karyawan PT. Bank Pembangunan Daerah Jawa Timur Tbk. Kantor Pusat Surabaya sudah memperoleh kesuksesan karir subjektif yang didukung oleh data yang menunjukan rendahnya angka rotasi pekerjaan dalam perusahaan. Idealnya sesuai dengan teori, self-efficacy berpengaruh terhadap kesuksesan karir. Dalam perusahaan, karyawan masih memiliki tingkat self-efficacy yang rendah akan tetapi karyawan telah merasa puas dengan karirnya.

Perilaku inovatif menurut Scott dan Bruce (1994) dalam Muluk dan Etikariena (2014) didefinisikan sebagai tindakan individu yang menghasilkan ide-ide yang bermanfaat dan memperluasnya ke anggota organisasi lainnya, inovasi dimulai ketika muncul sebuah masalah kemudian membuat ide atau solusi baik yang baru maupun yang diadaptasi dari luar organisasi. Menurut De Jong dan Hartog (2007) dalam Runhaar et al. (2013) menyatakan bahwa perilaku inovatif lebih diarahkan untuk menghasilkan, memperkenalkan dan mengaplikasikan suatu hal baru yang memberikan manfaat untuk organisasi. Perilaku inovatif terkait dengan kreativitas, namun perilaku inovatif ini lebih kompleks jika dibandingkan dengan kreativitas karena perilaku inovatif sampai pada tahap mengaplikasikan ideide yang telah diciptakan. Dapat disimpulkan bahwa Perilaku Inovatif adalah suatu tindakan yang memunculkan ide dan tindakan baru maupun yang di adaptasi dari luar organisasi, yang nantinya bermanfaat untuk organisasi tersebut.

Menurut Muluk dan Etrikariena (2014) perilaku inovatif dipengaruhi oleh faktor internal seperti tipe kepribdian dan gaya individu dalam memecahkan masalah. Faktor eksternal yaitu kepemimpinan dan dukungan untuk berinovasi. Sedangkan menurut Woods et al. (2018) perilaku inovatif dipengaruhi oleh keterbukaan dan kesadaran.

Penelitian ini menggunakan indikator dari Scott dan Bruce (1994). Indikator dari Scott dan 
Bruce (1994) sesuai dengan kondisi di perusahaan dimana perusahaan yang digunakan dalam penelitian ini merupakan organisasi inovatif. Selain itu, indikator ini paling sesuai untuk mengukur perilaku inovatif dalam sebuah team work.

Kesuksesan karir didefinisikan sebagai output dari keberhasilan kerja dan juga pencapaian kerja yang meimiliki dampak positif secara psikologis (Seibert et al. 2001). Liu et al. (2015) menyatakan bahwa kesuksesan karir mengacu pada sarana yang mewujudkan pencapaian dan akuisisi daya melalui masa hidup vokasional. Turban et al. (2016) menjelaskan bahwa kesuksesan karir berasal dari karakteristik individu yang biasanya dikonseptualisasikan sebagai model mobilitas kontes, atau dukungan dan sponsor dari orang lain dilingkungan kerja. Dengan demikian, kesuksesan karir lebih besar ketika individu memiliki karakteristik tertentu dan didukung oleh individu yang lain. Berdasarkan pengertian diatas dapat disimpulkan bahwa kesuksesan karir adalah perasaan positif terhadap pekerjaan sehingga menghasilkan suatu prestasi yang bermanfaat untuk perkembangan karir dan kepuasan karir.

Menurut Tohardi (2002) faktor-faktor yang mempengaruhi kesuksesan karir yaitu pengalaman, pendidikan, dan prestasi. Sedangkan menurut $\mathrm{Ng}$ et al. (2005) kesuksesan karir dipengaruhi oleh status sosial-dempografis, modal manusia, perbedaan individu stabil, dan sponsor organisasi.

Penelitian ini menggunakan indikator menurut Li et al. (2013). Indikator tersebut dipilih karena sesuai untuk mengukur kesuksesan karir karyawan di perusahaan yang dinilai tidak hanya sebatas pada pendapatan secara materiil melainkan lebih mengarah pada kesuksesan secara subjektif.

Self-Efficacy menurut Bandura (1978) dalam Fida et al. (2016) didefinisikan sebagai keyakinan yang dimiliki individu terkait dengan kemampuannya dalam mengkontrol dan melakukan tindakan yang sekiranya diperlukan untuk mengelola situasi tertentu. Hal ini merupakan ekspresi dari keterampilan individu dalam mempengaruhi cara mereka mengatur perilaku, pikiran, pilihan yang dibuat individu, serta upaya dan ketekunan yang mereka lakukan. Individu dapat berhasil mencapai tujuan mereka di bawah situasi yang menantang jika mereka percaya memiliki kemampuan untuk melakukan serangkaian tindakan yang diperlukan. Secara keseluruhan, Self-Efficacy telah terbukti melindungi terhadap faktor-faktor psikologis negatif seperti stres, burnout, dan kesehatan mental yang buruk.
Schwarzer et al. (2005) menjelaskan bahwa self-efficacy adalah keyakinan yang dimiliki pada diri seseorang terkait dengan kemampuannya dalam menghadapi segala tuntutan tugas dan pekerjaan. Selain itu self-efficacy mampu menentukan seberapa besar usaha yang perlu dilakukan oleh seseorang dalam sebuah kegiatan serta seberapa lama waktu yang dibutuhkan untuk menghadapi tantangan tersebut. Berdasarkan pengertian yang telah dipaparkan oleh para ahli, maka dapat disimpulkan bahwa Self-Efficacy adalah rasa percaya diri terhadap kemampuan yang dimiliki yang dapat mendorong suatu individu untuk dapat menyelesaikan pekerjaan dengan baik dan mampu menghadapi tantangan dalam pekerjaan.

Menurut Chasanah (2008) self-efficacy dipengaruhi oleh pengalaman keberhasilan, pengalaman orang lain, persuasi verbal, dan keadaan fisiologis atau afektif. Sedangkan menurut Bandura (1998) yang mempengaruhi self-efficacy adalah sifat tugas yang dihadapi, intensif eksternal reward yang diterima orang lain, status atau peran individu dalam lingkungannya, dan informasi mengenai kemampuan dirinya.

Penelitian ini menggunakan indikator menurut Schwarzer et al. (1997). Indikator ini dipilih karena sesuai dengan fenomena yang ada pada perusahaan karena terdapat target yang harus dicapai dalam pekerjaan dimana hal tersebut merupakan tantangan yang harus dihadapi oleh karyawan, oleh sebab itu perlu untuk mengukur tingkat kemampuan individu dalam mengatasi kesulitan dan tingkat kekuatan individu dalam menghadapi tugas dan tuntutan dalam perusahaan.

Dalam menghadapi globalisasi yang mengakibatkan persaingan bisnis semakin ketat, organisasi perlu mengoptimalkan seluruh aspek yang dimiliki. Sumber daya yang sangat dominan perannya dalam sebuah organisasi adalah karyawan. Sumber daya manusia memegang peranan penting dalam sebuah organisasi, karena berhasil atau tidaknya tujuan organisasi tergantung pada kemampuan sumber daya manusia dalam menjalankan tugas dan fungsinya. Oleh karena itu, organisasi perlu mempertimbangkan cara untuk mempertahankan karyawan yang berkompetensi.

Adanya perubahan yang terjadi akibat persaingan dalam dunia bisnis yang semakin ketat cenderung memberikan dampak terhadap kesuksesan karir dalam organisasi. Untuk memperkecil kemungkinan terjadinya dampak negatif dari adanya perubahan akibat persaingan dalam dunia bisnis, perusahaan dapat 
mengidentifikasi beberapa faktor yang dapat mempengaruhi kesuksesan karir, yaitu perilaku inovatif.

Berdasarkan latar belakang dan kajian pustaka dapat dikemukakan kerangka berpikir yang dapat dilihat pada Gambar 1.

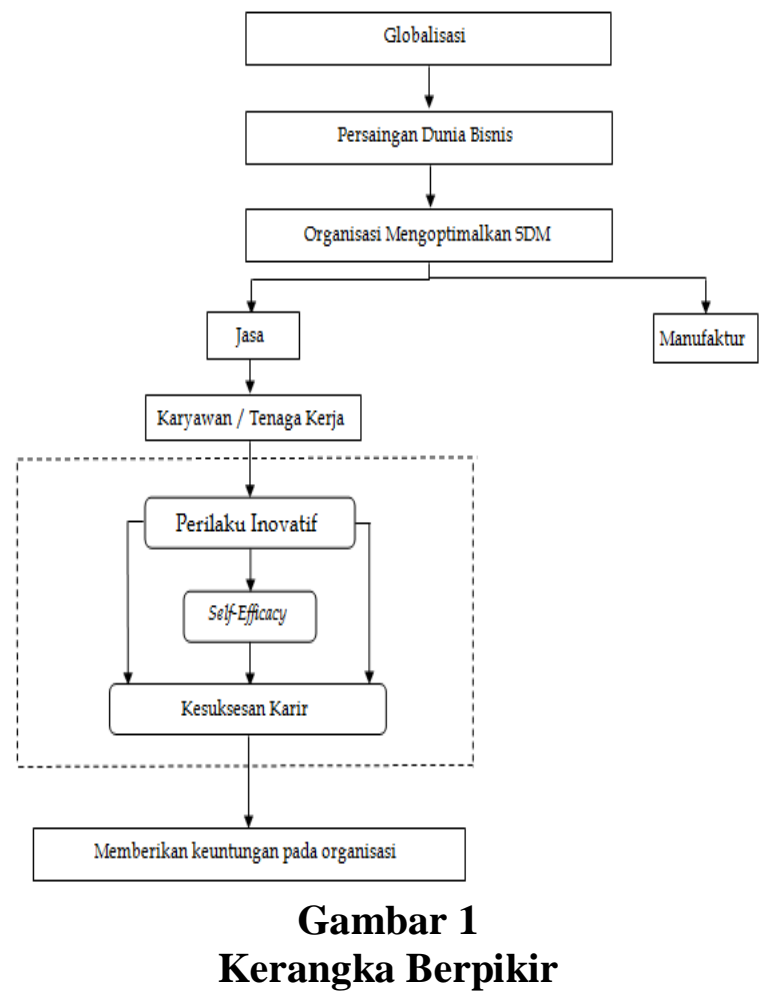

Perilaku inovatif tidak hanya dapat mempengaruhi kesuksesan karir, tetapi juga dapat mempengaruhi self-efficacy. Menurut Bandura (1994) dalam Fida et al. (2016), self-efficacy adalah keyakinan yang dimiliki individu tentang kemampuan mereka untuk mengatur dan melaksanakan tindakan yang diperlukan untuk mengelola situasi prospektif, maka dapat dikatakan bahwa self-efficacy dapat mengindikasi terciptanya kesuksesan karir.

Jika tingkat kesuksesan karir dalam perusahaan tinggi, maka hal tersebut dapat memberikan keuntungan untuk perusahaan. Misalnya, kinerja karyawan semakin meningkat karena terciptanya suasana kerja yang menyenangkan akibat terjalinnya hubungan baik antara karyawan dan kepuasan karir yang baik.

Berdasarkan teori yang dikemukakan oleh para ahli dalam penelitian terdahulu diatas, maka penelitian ini berfokus untuk membuktikan pengaruh dari perilaku inovatif terhadap kesuksesan karir melalui self-efficacy. Kerangka konseptual dalam penelitian ini dapat dilihat pada Gambar 2.

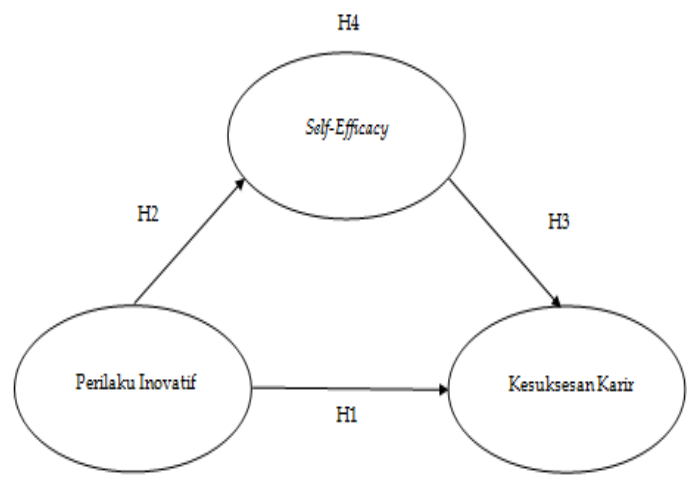

Gambar 2

Kerangka Konseptual

Berdasarkan teori dari penelitian terdahulu yang telah dikemukakan diatas, maka penulis mengajukan hipotesis sebagai berikut :

H1 : Diduga Perilaku Inovatif berpengaruh signifikan positif terhadap Kesuksesan Karir.

H2 : Diduga Perilaku Inovatif berpengaruh signifikan positif terhadap Self-Efficacy.

H3 : Diduga Self-Efficacy berpengaruh signifikan positif terhadap Kesuksesan Karir.

H4 : Diduga Perilaku Inovatif berpengaruh terhadap Kesuksesan Karir melalui SelfEfficacy.

\section{METODE PENELITIAN}

Penelitian ini adalah penelitian kuantitatif. Metode kuantitatif digunakan dalam penelitian ini karena diperlukan untuk mengetahui hubungan kausalitas antar variabel yang akan diteliti dan digunakan untuk menguji hipotesis yang telah ditetapkan Sugiyono (2018). Variabel independen penelitian ini adalah perilaku inovatif, sedangkan variabel dependennya yaitu kesuksesan karir dan variabel intervening ialah self-efficacy. Peelitian dilakukan di PT Bank Pembangunan Daerah Jawa Timur Tbk Kantor Pusat Surabaya, yang berlokasi di Jl. Basuki Rachmat No 98-104 Surabaya.

Menurut Sugiyono (2018) populasi merupakan wilayah generalisasi yang terdiri dari obyek/subyek yang mempunyai kualitas dan karakteristik tertentu yang ditetapkan oleh peneliti untuk dipelajari dan kemudian ditarik kesimpulan. Penelitian ini menggunakan populasi karyawan yang berjumlah 784 karyawan pada seluruh divisi PT. Bank Pembangunan Daerah Jawa Timur Tbk Kantor Pusat Surabaya.

Sampel penelitian diambil menggunakan teknik nonprobability sampling yaitu purposive sampling. Teknik pengambilan sampel ini tidak memberikan peluang yang sama bagi setiap 
anggota populasi untuk dipilih menjadi sampel (Sugiyono, 2018). Purposive sampling digunakan karena pengambilan sampel berdasarkan pertimbangan tertentu (Sugiyono, 2018). Pertimbangan pengambilan sampel yaitu karyawan yang diberikan kebebasan untuk melakukan inovasi. Teknik ini digunakan karena jumlah sampel yang dapat digunakan telah ditetapkan oleh perusahaan yang dijadikan sebagai obyek penelitian, adapun jumlah sampel yang dapat digunakan yaitu sebanyak 89 karyawan.

Menurut Sugiyono (2018), instrumen penelitian adalah suatu alat yang digunakan untuk mengukur fenomena alam maupun sosial yang diamati secara spesifik, semua fenomena ini disebut sebagai variabel penelitian.

Kuesioner dalam penelitian ini digunakan sebagai instrumen penelitian yang nantinya akan mengukur variabel penelitian Perilaku Inovatif, Kesuksesan Karir dan Self-Efficacy. Penelitian ini menggunakan kuesioner tertutup sehingga respon dapat dengan mudah dalam menjawab karena pilihat jawaban sudah tersedia di dalamnya. Pada Tabel 1 dapat dilihat instrumen yang akan digunakan.

\section{Tabel 1}

Instrumen Penelitian

\begin{tabular}{clc}
\hline Variabel & \multicolumn{1}{c}{ Indikator } & Item Pernyataan \\
\hline Perilaku & Dukungan untuk & $\mathbf{1 - 1 5}$ \\
Inovatif & Kreativitas & \\
\cline { 2 - 3 } (Scott, 1994) & Toleransi Perbedaan & $\mathbf{1 6 - 2 2}$ \\
\hline $\begin{array}{c}\text { Self-Efficacy } \\
\text { (Schwarzer } \text { et } \\
\text { al.,1997) }\end{array}$ & Tingkat kesulitan tugas & $\mathbf{2 3 - 2 6}$ \\
\cline { 2 - 3 } & Luas bidang tugas & $\mathbf{2 7 - 2 9}$ \\
\cline { 2 - 3 } $\begin{array}{l}\text { Kesuksesan } \\
\text { Karir }\end{array}$ & Kemampuan keyakinan & $\mathbf{3 0 - 3 2}$ \\
\cline { 2 - 3 } (Li et al., 2015) & $\begin{array}{l}\text { Daya Saing Organisasi } \\
\text { yang Dirasakan }\end{array}$ & $\mathbf{3 3 - 3 7}$ \\
\cline { 2 - 3 } & $\begin{array}{l}\text { Persepsi Daya Saing } \\
\text { Organisasi Eksternal }\end{array}$ \\
\hline
\end{tabular}

Sumber: Diolah Peneliti

Skala likert digunakan sebagai skala pengukuran dalam penelitian ini. Skala ini diharapkan mampu mengukur persepsi, sikap, dan juga pendapat dari responden penelitian. Skala likert dalam penelitian ini dapat dilihat pada Tabel 2.

\section{Tabel 2}

Skala Likert

\begin{tabular}{clcc}
\hline No & \multicolumn{1}{c}{ Pernyataan } & Kode & Skor \\
\hline 1 & Sangat Tidak Setuju & STS & 1 \\
\hline 2 & Tidak Setuju & TS & 2 \\
\hline 3 & Tidak Berpendapat/Netral & N & 3 \\
\hline 4 & Setuju & S & 4 \\
\hline 5 & Sangat Setuju & SS & 5 \\
\hline
\end{tabular}

Sumber: Diolah Peneliti
Teknik pengumpulan data dalam penelitian ini menggunakan kuesioner dan observasi. Sumber data menggunakan data primer dan data sekunder. Data primer merupakan data yang diperoleh dari pengamatan secara langsung. Selain itu dapat menggunakan wawancara dan memberikan kuesioner yang naninya akan dijawab oleh responden. Hasil tersebut nantinya kan dianalisis untuk mengetahui hasil signifikan atau tidak signifikan. Sedangkan data sekunder adalah sumber data yang tidak langsung memberikan data kepada pengumpul data, misalnya lewat orang lain atau lewat dokumen. Data sekunder disini mampu memberikan informasi siap pakai untuk pengambilan keputusan dalam penelitian ini meskipun data sekunder ini nantinya dapat diolah lebih lanjut (Sugiyono 2018).

Teknik analisis data dalam penelitian ini menggunakan uji validitas dan uji reliabilitas. Valid atau tidaknya kuesioner ini dapat diketahui melalui uji validitas. Ketika kuesioner mampu mengungkap maksud dari apa yang ingin diukur maka dapat dikatakan bahwa kuesioner tersebut telah valid (Ghozali, 2014). Nilai AVE model yang baik jika nilainya lebih dari 0,05 , dengan melihat nilai tersebut uji validitas dapat dilakukan (Ghozali, 2014). Instrumen dikatakan valid jika mampu mengukur apa yang ingin diukur.

Uji reliabiltas digunakan untuk mengetahui konsistensi dari kuesioner penelitian. Kuesioner dikatakan baik apabila ketika diukur berkali-kali kuesioner tersebut konsisten, dan untuk mengetahui hal tersebut dapat dilakukan dengan menggunakan uji reliabilitas (Ghozali, 2014). Composite reliability dan cronbach alpha digunakan dalam penelitian ini untuk mengukur reliabilitas penelitian ini. Jika nilainya lebih dari 0,70 maka reliabilitasnya dikatakan baik (Ghozali, 2014).

Analisis statistik deskriptif berguna untuk menggambarkan hasil dari data yang telah terkumpul kemudian dapat ditarik kesimpulan yang dapat berlaku untuk umum (Sugiyono, 2018:147). Penelitian ini menggunakan skala likert yang memiliki lima kategori, berkisar antara skor 5 (sangat setuju) sampai 1 (sangat tidak setuju).

Analisis statistik inferensial berguna untuk mengolah data dari sampel yang telah diambil dari populasi. Analisis statistik ini sangat tepat jika populasi yang digunakan untuk mengambil sampel jelas dan mencakup semua populasi (Sugiyono, 2018:147).

Hipotesis dalam penelitian ini diuji menggunakan teknik Structural Equation Model 
(SEM) dengan menggunakan software smartPLS. Partial Least Square (PLS) merupakan teknik analisis yang dapat digunakan pada seluruh skala data, tidak memerlukan sampel yang besar serta tidak perlu banya asumsi. Untuk melihat hubungan antar variabel juga dapat menggunakan software ini (Ghozali, 2014).

\section{PEMBAHASAN}

Berdasarkan hasil karakteristik responden karyawan berusia 20-29 tahun sebanyak 51 orang, usia 30-39 sebanyak 32 orang, usia 40-49 sebanyak 3 orang, dan usia 50-59 sebanyak 3 orang. Responden dengan jenis kelamin laki-laki sebanyak 56 orang, sedangkan yang berjenis kelamin perempuan sebanyak 33 orang. Responden dengan pendidikan terakhir D3 sebanyak 3 orang, pendidikan terakhir S1 sebanyak 80 orang, dan pendidikan terakhir S2 sebanyak 6 orang. 53 orang responden telah menikah dan 36 responden belum menikah. Masa kerja 1-5 tahun sebanyak 59 orang, 6-10 tahun sebanyak 23 orang, 11-15 tahun sebanyak 2 orang, 23-30 tahun sebanyak 1 orang, dan 31-40 tahun yaitu sebanyak 4 orang.

Hasil analisis deskriptif dari jawaban responden mengenai perilaku inovatif nilai tertinggi yaitu indikator dukungan untuk kreatif dengan rata-rata 3,40 (sedang). Selanjutnya, indikator toleransi perbedaan memiliki nilai rata-rata 3,40 (sedang). Dapat disimpulkan bahwa perilaku inovatif karyawan PT Bank Pembangunan Daerah Jawa Timur Tbk Kantor Pusat Surabaya masih terbilang sedang yaitu dengan skor rata-rata 3,47.

Nilai tertinggi mengenai self-efficacy yaitu pada indikator kemampuan keyakinan dengan skor ratarata 3,74 (tinggi). Kemudian indikator luas bidang tugas memiliki skor rata-rata 3,73 (tinggi), dan idikator tingkat kesulitan tugas memiliki skor ratarata 3,65 (sedang). Dapat disimpulkan bahwa selfefficacy yang dimiliki karyawan PT Bank Pembangunan Daerah Jawa Timur Tbk Kantor Pusat Surabaya sangat baik yaitu pada kategori tinggi dengan skor rata-rata 3,71.

Nilai tertinggi mengenai kesukesan karir yaitu pada indikator persesi daya saing organisasi eksternal dengan skor rata-rata 3,59 (sedang). Kemudian indikator kepuasan kerja memiliki skor rata-rata 3,55 (sedang), dan indikator daya saing organisasi yang dirasakan memiliki skor rata-rata 3,53 (sedang). Dapat disimpulkan bahwa kesuksesan karir karyawan PT. Bank Pembangunan Daerah Jawa Timur Tbk Kantor Pusat Surabaya masih terbilang sedang yaitu dengan skor rata-rata 3,56.

\section{Hasil Analisis Statistik Inferensial}

Structural Equation Modeling dengan menggunakan software Smart PLS versi 3.0. PLS digunakan untuk menguji hipotesis pada penelitia ini. 89 karyawan digunakan sebagai sampel sehingga analisis menggunakan PLS lebih tepat.

Analisis SEM-PLS dilakukan menggunakan beberapa penilaian diantaranya menilai model pengukuran (outer model) dan model struktural (inner model). Hipotesis dalam penelitian ini adalah pengaruh perilaku inovatif terhadap kesuksesan karyawan melalui self-efficacy karyawan PT Bank Pembangunan Daerah Jawa Timur Tbk Kantor Pusat Surabaya. Seluruh indikator dianggap valid jika nilai lebih dari 0,70 , namun jika nilai loading 0,50 sampai 0,60 dianggap cukup (Ghozali, 2014).

Berdasarkan uji measurement model nilai loading faktor dapat dilihat sebagai berikut:

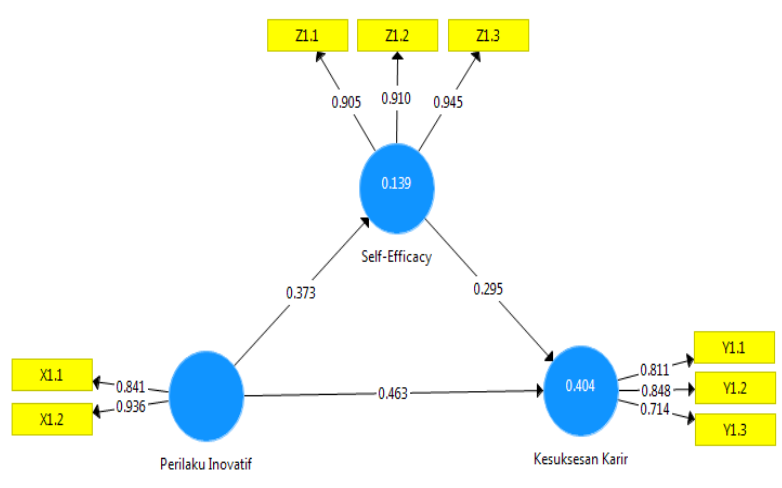

Gambar 3

Uji Measurement Model

Sumber: Output SmartPLS 3.2.8 (2019)

Pada Tabel 3 hasil menunjukan bahwa seluruh indikator perilaku inovatif valid, dikarenakan nilai seluruh item $>0,70$.

\section{Tabel 3}

Outer Loading Variabel Perilaku Inovatif

\begin{tabular}{ccc}
\hline Item & Outer Loading & Keterangan \\
\hline X1.1 & 0,841 & Valid \\
\hline X1.2 & 0,936 & Valid \\
\hline
\end{tabular}

Sumber: Output SmartPLS 3.2.8 (2019)

Pada Tabel 4 hasil menunjukan bahwa seluruh indikator self-efficacy valid, dikarenakan nilai dari seluruh item $>0,70$. 
Tabel 4 Outer Loading Variabel Self-Efficacy

\begin{tabular}{ccc}
\hline Item & Outer Loading & Keterangan \\
\hline Z1.1 & 0,905 & Valid \\
\hline Z1.2 & 0,910 & Valid \\
\hline Z1.3 & 0,945 & Valid \\
\hline Sumber : Output SmartPLS 3.2.8 (2019)
\end{tabular}

Tabel 5

Outer Loading Variabel Kesuksesan Karir

\begin{tabular}{ccc}
\hline Item & Outer Loading & Keterangan \\
\hline Y1.1 & 0,811 & Valid \\
\hline Y1.2 & 0,848 & Valid \\
\hline Y1.3 & 0,714 & Valid \\
\hline
\end{tabular}

Sumber: Output SmartPLS 3.2.8 (2019)

Pada Tabel 5 hasil menunjukan bahwa semua indikator kesuksesan karir valid, dikarenakan semua item memiliki nilai $>70$. Berdasarkan tabel 4.5 4.6 Dan 4.7 dapat diketahui bahwa seluruh variabel memiliki convergent validity yang baik, karena nilai outer loading $>0,70$.

Untuk mengetahui sejauh mana hasil pengukuran ini konsisten maka dapat menggunakan composite reliability. Composite reliability dapat digunakan untuk menguji nilai reliabilitas antara blok indikator dan konstruk yang membentuknya.

Tabel 6

Composite Reliability Variable

\begin{tabular}{cc}
\hline Variabel & Composite Reliability \\
\hline Perilaku Inovatif & 0,883 \\
\hline Self-Efficacy & 0,943 \\
\hline Kesuksesan Karir & 0,835 \\
\hline
\end{tabular}

Sumber: Output SmartPLS 3.2.8 (2019)

Berdasarkan Tabel 6 dapat diketahui bahwa nilai composite reliability dari seluruh variabel lebih besar dari 0,70. Maka dapat disimpulkan bahwa model variabel tersebut telah memiliki reliabilitas yang baik karena telah memenuhi composite reliability.

Untuk mengevaluasi konsistensi dapat menggunakan cronbach's alpha. Hasil ini akan memperkuat hasil yang telah diuji sebelumnya pada composite reliability. Hasil dapat dilihat pada tabel berikut:

Tabel 7

Cronbach's Alpha Variable

\begin{tabular}{cc}
\hline Variabel & Cronbach's Alpha \\
\hline Perilaku Inovatif & 0,747 \\
\hline Self-Efficacy & 0,910 \\
\hline
\end{tabular}

\begin{tabular}{cc}
\hline Kesuksesan Karir & 0,709 \\
\hline Sumber: Output SmartPLS 3.2.8 (2019)
\end{tabular}

Sumber: Output SmartPLS 3.2.8 (2019)

Nilai cronbach's alpha dapat digunakan jika lebih dari 0,60 (Siregar, 2014). Berdasarkan Tabel 7 dapat diketahui bahwa model variabel mempunyai reliabilitas yang baik karena nilai dari semua konstruk >0,60.

Tabel 8

Nilai R-Square Model

\begin{tabular}{cc}
\hline Variabel & R-Square \\
\hline Perilaku Inovatif & \\
\hline Self-Efficacy & 0,139 \\
\hline Kesuksesan Karir & 0,404 \\
\hline
\end{tabular}

Sumber: Output SmartPLS 3.2.8 (2019)

Pada Tabel 8 Hasil menunjukan bahwa perilaku inovatif pada self-efficacy memiliki nilai R-Square 0,139 sehingga dapat diartikan variabel perilaku inovatif mampu menjelaskan self-efficacy sebesar $14 \%$. Kemudian sebesar $86 \%$ variabel lain yang tidak ada pada penelitian ini dapat menjelaskan self-efficacy pada PT Bank Pembangunan Daerah Jawa Timur Tbk Kantor Pusat Surabaya.

Pada Tabel 8 dapat diketahui model pengaruh perilaku inovatif terhadap kesuksesan karir memiliki R-Square 0,404 sehingga diartikan bahwa $40 \%$ perilaku inovatif mampu menjelaskan kesuksesan karir. Kemudian $60 \%$ variabel lain yang tidak ada pada penelitian ini dapat menjelaskan kesuksesan karir pada PT Bank Pembangunan Daerah Jawa Timur Tbk Kantor Pusat Surabaya.

Q-Square predictive relevance dapat digunakan utuk mengevaluasi model PLS. Nilai dapat dilihat dalam perhitungan berikut ini :

$$
\begin{aligned}
& =1-\left(\sqrt{ } 1-\mathrm{R} 1^{2}\right) \times\left(\sqrt{ } 1-\mathrm{R} 2^{2}\right) \\
& =1-\left(\sqrt{ } 1-0,139^{2}\right) \times\left(\sqrt{ } 1-0,404^{2}\right) \\
& =1-(\sqrt{ } 0,980) \times(\sqrt{ } 0,836) \\
& =1-(0,989 \times 0,914) \\
& =0,09
\end{aligned}
$$

Dari perhitungan diatas diperoleh nilai QSquare predictive relevance sebesar 0,09 dimana nilai tersebut lebih besar dari nol. Hal tersebut menunjukan model memiliki predictive relevance yang dapat menjelasakan model sebesar 9\%.

Inner model dapat digunakan untuk melihat hubungan antar konstruk dan nilai signifikansi pada tabel path coefficients yang dapat dilihat pada Tabel 9 dibawah ini. 
Tabel 9

Hasil Path Coefficient

\begin{tabular}{|c|c|c|c|c|}
\hline $\begin{array}{c}\text { Hubungan } \\
\text { Antara } \\
\text { Variabel }\end{array}$ & $\begin{array}{l}\text { Original } \\
\text { Sample }\end{array}$ & $\begin{array}{c}\text { T- } \\
\text { Statistics }\end{array}$ & Keterangan & kesimpulan \\
\hline $\begin{array}{c}\text { Perilaku } \\
\text { Inovatif } \rightarrow \\
\text { Kesuksesan } \\
\text { Karir }\end{array}$ & 0,436 & 4,767 & $\begin{array}{c}\geq 1,96 \\
\text { (Signifikan) }\end{array}$ & $\begin{array}{l}\text { Hipotesis } \\
\text { Diterima }\end{array}$ \\
\hline $\begin{array}{c}\text { Perilaku } \\
\text { Inovatif } \rightarrow \\
\text { Self-Efficacy }\end{array}$ & 0,373 & 2,592 & $\begin{array}{c}\geq 1,96 \\
\text { (Signifikan) }\end{array}$ & $\begin{array}{l}\text { Hipotesis } \\
\text { Diterima }\end{array}$ \\
\hline $\begin{array}{c}\text { Self-Efficacy } \\
\rightarrow \\
\text { Kesuksesan } \\
\text { Karir }\end{array}$ & 0,295 & 2,588 & $\begin{array}{c}\geq 1,96 \\
\text { (Signifikan) }\end{array}$ & $\begin{array}{l}\text { Hipotesis } \\
\text { Diterima }\end{array}$ \\
\hline
\end{tabular}

Sumber: Output SmartPLS 3.2.8 (2019)

Perilaku inovatif memiliki pengaruh yang signifikan terhadap kesuksesan karir dengan nilai tstatistic 4,767>1,96. Hasil nilai koefisien estimate menunjukan bahwa semakin tinggi perilaku inovatif maka kesuksesan karir semakin tinggi pula, ini dikarenakan nilai sebesar 0,436. Dapat disimpulkan adanya perbandingan lurus karena nilai adalah positif.

Perilaku inovatif memiliki pengaruh signifikan terhadap self-efficacy dengan nilai t-statistic 2,592 $>1,96$. Nilai koefisien estimate sebesar 0,373 yang berarti semakin tinggi perilaku inovatif maka semakin tinggi pula self-efficacy karyawan. Dapat dilihat adanya perbandingan lurus karena nilai adalah positif.

Self-efficacy mempunyai pengaruh signifikan terhadap kesuksesan karir karena nilai t-statistic $2.588>1,96$. Kemudian untuk nilai koefisien estimate yaitu 0,295 berarti semakin tinggi selfefficacy akan semakin tinggi pula kesuksesan karir karyawan. Dapat disimpulkan adanya perbandingan lurus karena nilai adalah positif.

Tabel 10

Hasil Indirect Effect

\begin{tabular}{ccccc}
\hline & $\begin{array}{c}\text { Original } \\
\text { Sample }\end{array}$ & $\begin{array}{c}\text { T- } \\
\text { Statistics }\end{array}$ & Keterangan & Kesimpulan \\
\hline $\begin{array}{c}\text { Perilaku } \\
\text { Inovatif } \\
\rightarrow\end{array}$ & 0,436 & 4,767 & Signifikan & $\begin{array}{c}\text { Hipotesis } \\
\text { Diterima }\end{array}$ \\
$\begin{array}{c}\text { Kesukses } \\
\text { an Karir }\end{array}$ & & & & \\
\hline $\begin{array}{l}\text { Perilaku } \\
\text { Inovatif } \\
\rightarrow \text { Self- }\end{array}$ & & & & \\
$\begin{array}{c}\text { Efficacy } \\
\rightarrow\end{array}$ & 0,110 & 1,918 & Tidak & Hipotesis \\
Kesukses & & & & Ditolak \\
an Karir & & & & \\
\hline Siliasi & & \\
\hline
\end{tabular}

Sumber: Output PLS 3.0 (2019)
Dari Tabel 10 dapat diketahui bahwa nilai koefisien perilaku inovatif terhadap kesuksesan karir yaitu sebesar 4,767. Hal ini menunjukan bahwa terdapat pengaruh yang sigifikan pada variabel perilaku inovatif terhadap kesuksesan karir. Sedangkan nilai koefisien perilaku inovatif terhadap kesuksesan karir melalui self-efficacy yaitu sebesar 1,918. Artinya nilai koefisien pengaruh perilaku inovatif terhadap kesuksesan karir melalui self-efficacy lebih kecil dari pengaruh secara langsung perilaku inovatif terhadap kesuksesan karir. Oleh sebab itu, dapat disimpulkan bahwa variabel self-efficacy tidak mampu memediasi pengaruh perilaku inovatif terhadap kesuksesan karir karyawan PT. Bank Pembangunan Daerah Jawa Timur Tbk Kantor Pusat Surabaya. Besarnya koefisien pengaruh langsung dan tidak langsung dapat dihitung menggunakan rumus menurut Hayes (2013) sebagai berikut:

Direct Effect: Perilaku Inovatif $\rightarrow$ Kesuksesan Karir $=0,436$

Indirect Effect: Perilaku Inovatif $\rightarrow$ Self-Efficacy $\rightarrow$ Kesuksesan Karir $=(0,373) \times(0,295)=0,110$

Berdasarkan perhitungan diatas dapat disimpulkan bahwa pengaruh secara langsung memiliki nilai lebih besar dibandingkan dengan nilai pengaruh secara tidak langsung. Sehingga dapat diartikan bahwa self-efficacy tidak mampu memediasi hubungan dari perilaku inovatif dan kesuksesan karir.

Hasil penelitian berdasarkan analisis data empiris yang sehubungan dengan hipotesis yang diajukan, yaitu pengaruh perilaku inovatif terhadap kesuksesan karir melalui self-efficacy karyawan PT Bank Pembangunan Daerah Jawa Timur Tbk. Kantor Pusat Surabaya.

\section{Pengaruh Perilaku Inovatif Terhadap Kesuksesan Karir}

Hasil pengujian menunjukan bahwa perilaku inovatif berpengaruh positif signifikan terhadap kesuksesan karir. Hal ini diketahui dari data yang menunjukan bahwa nilai t-statistik memiliki nilai 4,767 yaitu lebih dari 1,96 sehingga H1 diterima.

Hasil penelitian ini memperkuat penelitian yang dilakukan oleh Aime et al. (2011) dan Seibert et al. (2001) yang mengatakan bahwa perilaku inovatif secara positif mempengaruhi kesuksesan karir. Mendorong perilaku inovatif akan memungkinkan karyawan untuk meningkatkan kepuasan serta kesuksesan karir mereka, selain itu inovasi mampu 
meningkatkan peran karyawan untuk mengarah pada kesuksesan karir subyektif.

Berdasarkan hasil penelitian jika terdapat pengaruh positif dan signifikan maka dapat dijelaskan bahwa semakin baik perilaku inovatif yang dimiliki karyawan PT Bank Pembagunan Daerah Jawa Timur Tbk Kantor Pusat Surabaya maka kesuksesan karir karyawan semakin baik pula. Berdasarkan hasil estimasi inner model diketahui bahwa perilaku inovatif terhadap kesuksesan karir memiliki koefisien estimate bertanda positif yaitu sebesar 0,436 . Hasil tersebut dapat diketahui bahwa perilaku inovatif memiliki pengaruh yang besar terhadap kesuksesan karir karyawan.

Perilaku inovatif yang dimiliki karyawan yaitu berupa inovasi-inovasi dalam mencari nasabah, misalnya karyawan memanfaatkan sosial media untuk memberikan informasi dan menawarkan keuntungan-keuntungan menjadi nasabah bank jatim. Semakin baik dukungan untuk kreativitas dan toleransi perbedaan, baik dalam menciptakan ide-ide kreatif maupun mencoba cara baru yang berbeda dalam memecahkan suatu masalah maka akan menyebabkan meningkatnya kesuksesan karir karyawan PT Bank Pembagunan Daerah Jawa Timur Tbk Kantor Pusat Surabaya. Selain itu, peningkatan kesuksesan karir karyawan juga dapat disebabkan oleh organisasi yang fleksibel serta terbuka dengan perubahan, adanya kebebasan bagi karyawan untuk merealisasikan ide-ide kreatif yang dimiliki, dan adanya dukungan ketika karyawan melakukan sesuatu yang berbeda dengan karyawan lainnya.

Melalui pengamatan yang peneliti lakukan, PT. Bank Pembagunan Daerah Jawa Timur Tbk Kantor Pusat Surabaya sangat mendukung dan mengapresiasi karyawan yang memiliki kreativitas tinggi. Hal ini dibuktikan dengan adanya The Best Employee Award yang diselenggarakan setiap tahunnya untuk memberikan apresiasi kepada karyawan yang berprestasi. Penghargaan tersebut bukan hanya sekedar apresiasi bagi karyawan, tetapi juga merupakan sebuah motivasi bagi seluruh karyawan untuk berprestasi dan meningkatkan kreativitasnya dalam menciptakan inovasi sehingga mampu memberikan layanan yang terbaik kepada masyarakat.

Hal ini juga didukung dengan hasil analisis deskriptif jawaban responden untuk variabel perilaku inovatif yaitu berada pada kategori sedang dengan nilai rata-rata 3,47 dan hasil analisis deskriptif variabel kesuksesan karir berada pada kategori sedang dengan nilai rata-rata 3,56.
Perilaku inovatif mampu untuk meningkatkan kesuksesan karir karyawan dengan memberikan kebebasan untuk karyawan dalam melakukan perubahan, serta memberi kebabasan pada karyawan untuk menggunakan kreativitas mereka dalam pekerjaan yang nantinya akan memberikan rasa puas bagi karyawan terhadap pekerjaannya sehingga mampu menciptkan kesuksesan karir karyawan.

Nilai terkecil terdapat pada salah satu pernyataan dalam indikator dukungan untuk kreativitas yaitu mendapat imbalan ketika tidak mengganggu anggota lain. Hal ini dapat diartikan bahwa karyawan merasa kurang mendapatkan imbalan ketika mereka medukung karyawan lain untuk menciptakan kreativitas dengan cara tidak mengganggu karyawan tersebut, misalnya ketika beker. Perusahaan perlu melakukan evaluasi dan memberikan apresiasi kepada karyawan ketika mereka mendukung karyawan lain untuk berinovasi, sehingga karyawan dapat menciptakan berbagai inovasi tanpa adanya hambatan dari karyawan lain yang nantinya akan berdampak pada kesuksesan karir mereka.

Berdasarkan hasil penelitian ini jika berpengaruh positif signifikan maka dapat dijelaskan bahwa semakin tinggi perilaku inovatif yang dimiliki karyawan maka kesuksesan karir karyawan akan semakin meningkat. Hasil estimasi inner model menggunakan software smartPLS dapat diketahui bahwa perilaku inovatif terhadap kesuksesan karir memiliki nilai koefisien estimate bertanda positif yaitu sebesar 0,436. Berdasarkan hasil tersebut dapat disimpulkan bahwa perilaku inovatif memiliki pengaruh yang besar terhadap kesuksesan karir karyawan PT Bank Pembangunan Daerah Jawa Timur Tbk Kantor Pusat Surabaya.

Peningkatan kesuksesan karir ini dikarenakan perusahaan sangat fleksibel dan selalu berusaha beradaptasi dan selalu terbuka dengan perubahan, misalnya di era digital saat ini perusahaan terus meningkatkan layanan yang berbasis teknologi seperti internet banking, mobile banking, dan juga mengembangkan teknologi QR Code untuk kemudahan transaksi e-banking. Dukungan lainnya terhadap inovasi juga diberikan oleh perusahaan dalam bentuk materiil, yaitu dengan mengalokasikan anggaran sebesar Rp.50 miliar pada tahun 2018 untuk mendukung pengembangan teknologi informasi.

Dukungan terhadap inovasi dan perubahan yang diberikan perusahaan sangat mendukug terciptanya perilaku inovatif karyawan, karyawan semakin mudah untuk berkreativitas dan merealisasikan 
ide-ide kreatifnya karena kebebasa dan dukungan dari perusahaan. Hal tersebut menjadikan karyawan mampu menghadapi situasi yang menantang dan mampu beradaptasi dengan ide-ide atau teknologi baru. Karyawan dalam perusahaan memiliki target yang harus dicapai untuk mendapatkan manajemen karir, oleh sebab itu karyawan harus mampu mencari cara agar mampu mencapai target tersebut dengan berbagai usaha diantaranya dengan cara ide-ide kreatif. Ketika karyawan mampu menciptakan cara-cara baru yang inovatif serta memberikan dukungan dan toleransi pada cara-cara baru yang digunakan dalam menyelesaikan dan memenuhi target pekerjaan, maka akan semakin mendorong pengembangan dan penigkatan karir karyawan.

Berdasarkan hasil analisis diatas dapat diketahui bahwa perilaku inovatif mampu mempengaruhi kesuksesan karir karyawan PT Bank Pembangunan Daerah Jawa Timur Tbk Kantor Pusat Surabaya. Semakin tinggi perilaku inovatif karyawan maka kesuksesan karirnya akan semakin meningkat.

\section{Pengaruh Perilaku Inovatif Terhadap Self- Efficacy}

Hasil pengujian menunjukan bahwa perilaku inovatif berpengaruh positif signifikan terhadap self-efficacy. Hal ini dapat diketahui dari data yang menunjukan bahwa nilai t-statistik sebesar 2,592 yaitu lebih dari 1,65 sehingga $\mathrm{H} 2$ diterima.

Hasil penelitian ini memperkuat penelitian yang dilakukan oleh Grosser et al. (2017) dan Runhaar et al. (2013) yang menyatakan bahwa perilaku inovatif berpengaruh positif terhadap self-efficacy. Perilaku inovatif karyawan mampu memfasilitasi seseorang untuk melakukan perubahan dalam menyelesaikan masalah dan menigkatkan selfefficacy yang merupakan karakteristik pribadi yang berharga.

Berdasarkan hasil penelitian ini jika berpengaruh positif signifikan maka dapat dijelaskan bahwa semakin tinggi perilaku inovatif yang dimiliki karyawan maka self-efficacy karyawan akan semakin meningkat. Hasil estimasi inner model menggunakan software smartPLS dapat diketahi bahwa perilaku inovatif terhadap self-efficacy memiliki nilai koefisien estimate bertanda positif yaitu sebesar 0,373. Berdasarkan hasil tersebut dapat disimpulkan bahwa perilaku inovatif memiliki pengaruh yang besar terhadap self-efficacy karyawan PT Bank Pembangunan Daerah Jawa Timur Tbk Kantor Pusat Surabaya.
Peningkatan self-efficacy ini dikarenakan perusahaan sangat fleksibel dan selalu berusaha beradaptasi dengan perubahan dan juga terbuka oleh setiap perubahan, sehingga mendukung karyawan agar mampu menciptakan pemikiranpemikiran kreatif yang nantinya mempermudah dalam mencari solusi dari sebuah masalah yang dihadapi. Selain itu, karyawan akan lebih percaya diri terhadap kemampuan yang dimiliki karena mampu dengan mudah menghadapi tantangantantangan dalam pekerjaan dengan perilaku inovatif yang dimiliki. Bekerja pada sebuah bank dituntut untuk mecapai target, oleh karena itu karyawan harus mempunyai cara bagaimana target tersebut dapat dicapai yaitu salah satunya dengan cara meningkatkan kepercayaan diri yang dimiliki.

Melalui hasil pengamatan yang penulis lakukan, karyawan memiliki kepercayaan diri yang tinggi ketika mereka mampu menciptakan kreativitas, hal ini terjadi karena perusahaan selalu memberikan reward setiap tahun pada The Best Employee Award, penghargaan ini diberika kepada karyawan yang berprestasi dan kreatif. Karyawan yang memperoleh penghargaan tentunya akan semakin percaya diri terhadap kemampuan yang dimiliki karena telah mendapat pengakuan dari perusahaan. Selain itu, perusahaan sangat mendukung adanya inovasi serta sangat terbuka terhadap prubahan. Hal ini dibuktikan bahwa setiap tahunnya perusahaan selalu melakukan inovasi baik pada produk yang dihasilkan perusahaan maupun pada layanan yang diberikan kepada nasabah. Inovasi-inovasi yang diciptakan oleh perusahaan tidak terlepas dari pemikiranpemikiran kreatif yang dimiliki oleh karyawannya.

Dukungan dan kebebasan yang diberikan perusahaan terhadap karyawan untuk berinovasi menjadikan karyawan lebih kreatif dan percaya diri terhadap kemampuan yang mereka miliki, dukungan yang diberikan perusahaan kepada karyawan ini misalnya berupa pemberian reward untuk karyawan yang berprestasi, dan tersedianya anggaran dana untuk inovasi. Selain itu perusahaan juga terbuka dengan perubahan, sebagai contoh kecil terdapat kotak saran disetiap ruangan divisi yang artinya perusahaan bersedia menerima kritik dan saran untuk sebuah perubahan yang positif. Kepercayaan diri ini muncul karena kemampuan yang dimiliki oleh karyawan dapat meningkat karena karyawan secara terus-menerus berusaha melakukan perubahan.

Hasil analisis deskriptif jawaban responden untuk variabel perilaku inovatif memiliki nilai ratarata sebesar 3,47 yang termasuk dalam kategori 
rendah. Sedangkan untuk variabel self-efficacy memiliki nilai rata-rata sebesar 3,71 yang termasuk dalam kategori tinggi. Perilaku inovatif mampu meningkatkan self-efficacy yang dimiliki karyawan, dibuktikan melalui dukungan perusahaan yang selalu memantau dan mengapresiasi pencapaian karyawan, pemberian reward dan manajemen karir mampu meningkatkan kepercayaan diri karyawan terhadap kemampuan yang dimiliki.

Nilai terkecil terdapat pada salah satu pernyataan dalam indikator tingkat kesulitan tugas yaitu jika seseorang menentang saya, saya dapat menemukan cara untuk mendapatkan apa yang saya inginkan.

Hal ini berarti karyawan merasa setiap pencapaiannya tergantung pada dukungan dari karyawan lain, misalnya ketika karyawan ingin menggunakan sosial media sebagai sarana untuk mendapatkan nasabah tetapi tidak didukung oleh karyawan lain karena mungkin dirasa kurang efektif, maka cara tersebut otomatis tidak dapat digunakan oleh karyawan tersebut. Oleh karena itu, karyawan perlu meningkatkan kemampuannya dalam meyakinkan karyawan lain bahwa inovasi yang dilakukan dapat memberikan manfaat positif, sehingga nantinya karyawan lain dapat mendukung setiap upaya yang dilakukan oleh sesama rekan kerja.

Berdasarkan hasil secara statistik dan pengamatan yang penulis lakukan di perusahaan, dapat diketahui bahwa perilaku inovatif mampu memberikan pengaruh terhadap self-efficacy karyawan. semakin baik inovasi yang dimiliki karyawan maka akan memicu self-efficacy yang semakin tinggi.

\section{Pengaruh Self-Efficacy Terhadap Kesuksesan Karir}

Hasil pengujian menunjukan bahwa selfefficacy berpengaruh positif signifikan terhadap kesuksesan karir. Hal ini diketahui dari data yang menunjukan bahwa nilai t-statistik memiliki nilai 2.588 yaitu lebih dari 1,65 sehingga $\mathrm{H} 3$ diterima.

Hasil penelitian ini memperkuat penelitian yang dilakukan oleh Hirschi \& Jeansch (2015) yang mengatakan bahwa self-efficacy secara positif mempengaruhi kesuksesan karir. Hal ini dikarenakan kepercayaan diri yang lebih besar mampu membuat seseorang lebih menguasai tantangan dalam karir mereka dan lebih terlibat dalam mengelola karirnya secara proaktif. Penelitian ini didukung oleh Spurk dan Abele (2014) yang menyatakan bahwa self-efficacy berpengaruh positif terhadap kesuksesan karir. Penelitian ini menunjukan bahwa self-efficacy pada awal karir individu memiliki efek langsung pada kesuksesan selanjutnya, maka menumbuhkan selfefficacy mampu menunjang keberhasilan dan peningkatan karir.

Berdasarkan hasil penelitian ini jika berpengaruh positif signifikan maka dapat dijelaskan bahwa semakin tinggi self-efficacy yang dimiliki karyawan maka kesuksesan karir karyawan semakin meningkat. Hasil estimasi inner model menggunakan software smartPLS dapat diketahui bahwa self-efficacy terhadap kesuksesan karir memiliki nilai koefisien estimate bertanda positif yaitu sebesar 0,295. Berdasarkan hasil tersebut dapat disimpulkan bahwa self-efficacy memiliki pengaruh yang besar terhadap kesuksesan karir.

Melalui informasi yang peneliti peroleh dari penelitian terdahulu yang dilakukan di PT Bank Pembangunan Daerah Jawa Timur Tbk Kantor Pusat Surabaya, menyatakan bahwa untuk mendapatkan manajemen karir seluruh karyawan dituntut untuk mencari nasabah setiap tahunnya. Karyawan harus mampu memperoleh nilai diatas 3 dari skala penilaian 1-5 yang telah ditetapkan oleh perusahaan.

Manajemen karir yang akan diperoleh karyawan ketika mampu mencapai target dari perusahaan diantaranya adalah pendidikan dan pelatihan program Staf Development Program (SDP), Manager Development Program (MDP), Executive Development Program (EDP). SDP ini diberikan dengan tujuan untuk memberikan pengetahuan dan keterampilan kepada karyawan di bidang manajerial perbankan (Managerial competencies), operasional perbankan (Technical competenccies) khususnya dibidang kredit, dan pemasaran dana. MDP ini digunakan untuk menempati posisi strategis di Bank Jatim menjadi manajer yang handal dan profesional pada masa yang akan datang. Pendidikan MDP ini dirancang dan dilaksanakan dalam bentuk yang lebih implementatif terhadap tugas pada posisi Pemimpin Bidang Operasional atau yang setingkat. Melalui program pendidikan ini diharapkan para peserta menjadi manager yang handal dan profesional dalam menghadapi setiap perubahanperubahan bisnis yang terjadi. EDP merupakan program untuk mempersiapkan calon-calon Pemimpin Cabang yang handal dan merupakan langkah strategis yang harus dilakukan oleh manajemen dalam mendukung keberhasilan bisnis Bank. Dalam mengukur kinerja calon Pemimpin 
Cabang Bank Jatim mempunyai sistem untuk mengukur Knowledge, Skill, dan Attitude para calon Pemimpin Cabang yang disesuaikan dengan level Hard dan Soft Competencies Pemimpin Cabang.

Hasil analisis deskriptif jawaban responden untuk variabel self-efficacy memiliki nilai rata-rata sebesar 3,71 yaitu termasuk pada kateori tinggi, sedangkan variabel kesuksesan karir memiliki nilai rata-rata sebesar 3,56 yaitu termasuk dalam kategori sedang. Self-efficacy mampu meningkatkan kesuksesan karir karyawan dengan rasa percaya diri dalam menghadapi tugas yang sulit serta keyakinan terhadap kemampuan yang dimiliki sehingga mampu mencapai target mencari nasabah yang diberikan oleh perusahaan.

Nilai terkecil terdapat pada salah satu pernyataan dalam indikator kepuasan karir yaitu saya puas dengan kesuksesan yang saya raih dalam karir saya.

Hal ini berarti karyawan merasa pencapaian yang mereka raih selama ini belum sesuai dengan target yang mereka inginkan. Hal ini dikarenakan sebagian karyawan belum mampu mencapai target mencari nasabah yang diberikan oleh perusahaan. Perusahaan memberikan nilai dengan skala 1-5 dimana karyawan harus mampu mencapai angka diatas 3 untuk mendapatkan mananjemen karir. Namun, hal tersebut tidak terlalu memberikan dampak yang merugikan perusahaan, karena pada pernyataan saya puas dengan kemajuan yang saya buat menuju tujuan untuk kemajuan karir saya memiliki nilai relatif tinggi. Artinya, meskipun karyawan sering merasa tidak puas dengan pencapainnya, namun karyawan selalu dapat memberikan kemajuan dan peningkatan pada perkembangan karirnya.

Peningkatan kesuksesan karir ini dikarenakan karyawan merasa mampu mengelola dan menyelesaikan masalah yang sulit ketika mereka berusaha cukup keras. Ketika karyawan mampu menyelesaikan tugas dan tantangan dalam pekerjaan dengan baik, maka akan tercipta kepuasan karir yang dirasakan oleh karyawan sehingga kesuksesan karir secara subyektif dapat tercapai. Self-efficacy diasumsikan mempengaruhi hasil dengan mengarahkan perhatian, memobilisasi usaha, mempengaruhi kegigihan, dan menyusun perilaku. Self-efficacy memungkinkan orientasi dan regulasi jangka panjang dari tindakan seseorang, sehingga self-efficacy dapat menjadi penentu keberhasilan karyawan. selain itu, self-efficacy merupakan kemampuan yang mampu memotivasi karyawan untuk berhasil melakukan tugas dan tantangan dalam pekerjaan.

Berdasarkan analisis diatas dapat diketahui bahwa self-efficacy mampu mempengaruhi kesuksesan karir karyawan PT Bank Pembangunan Daerah Jawa Timur Tbk Kantor Pusat Surabaya. Semakin tinggi self-efficacy yang dimiliki oleh karyawan maka kesuksesan karirnya akan semakin meningkat.

\section{Pengaruh Perilaku Inovatif Terhadap Kesuksesan Karir Melalui Self-Efficacy}

Hasil pengujian hipotesis menunjukan bahwa nilai koefisien dari pengaruh langsung perilaku inovatif terhadap kesuksesan karir adalah sebesar 4,767. Sedangkan pengaruh tidak langsung perilaku inovatif terhadap kesuksesan karir melalui self-efficacy memiliki nilai koefisien sebesar 1,918. Berdasarkan hasil tersebut dapat diartikan bahwa pengaruh perilaku inovatif terhadap kesuksesan karir melalui self-efficacy lebih kecil dari pada pengaruh secara langsung perilaku inovatif terhadap kesuksesan karir. Sehingga dapat disimpulkan bahwa variabel self-efficacy tidak mampu memediasi pengaruh perilaku inovatif terhadap kesuksesan karir karyawan PT Bank Pembangunan Daerah Jawa Timur Tbk Kantor Pusat Surabaya, dengan demikian hipotesis keempat ditolak.

Variabel mediasi dapat meningkatkan pengaruh variabel independen terhadap variabel dependen melalui fungsi mediasinya. Variabel mediasi diperlukan jika tidak ada pengaruh antara veriabel independen dengan variabel dependen atau pengaruh antara dua variabel tersebut sedikit. Sedangkan pada penelitian ini pengaruh perilaku inovatif terhadap kesuksesan karir memiliki nilai lebih besar dibadingkan nilai pengaruh melalui self-efficacy yang digunakan sebagai variabel mediasi.

Hasil penelitian ini berbeda dengan penelitian yang dilakukan oleh Dan et al. (2018) yang menyatakan bahwa perilaku inovatif berpengaruh signifikan positif terhadap kesuksesan karir melalui self-efficacy, hal ini dikarenakan individu dengan self-efficacy tinggi cenderung mencapai hasil yang sukses ketika mereka memiliki kesadaran akan inovasi dan mengimplementasikan di tempat kerja. Hasil yang berbeda juga ditunjukan oleh penelitian Xu et al. (2018) yang mengemukakan bahwa self-efficacy mampu memediasi pengaruh perilaku inovatif terhadap kesuksesan karir. Hal tersebut dikarenakan karyawan dengan self-efficacy yang kuat dan 
mengandalkan faktor-faktor seperti perilaku inovatif dan dukungan organisasi akan mampu menetapkan tujuan yang efektif. Oleh karena itu, karyawan dengan perilaku inovatif dan selfefficacy tingkat tinggi dapat memperkuat peluang mereka untuk sukses dalam karir. Hasil penelitian ini berbeda dengan penelitian-penelitian terdahulu karena karyawan dalam perusahaan menganggap bahwa tanpa adanya perilaku inovatif self-efficacy telah mampu mendorong terciptanya kesuksesan karir, mengingat tingkat self-efficacy yang dimiliki oleh karyawan berada pada skala tinggi dan sedang.

Berdasarkan hasil tersebut dapat ditarik kesimpulan bahwa pengaruh perilaku inovatif terhadap kesuksesan karir melalui self-efficacy tidak mampu memediasi dua variabel tersebut. Sehingga dapat diartikan bahwa self-efficacy dapat berdiri sendiri menjadi variabel yang mampu mempengaruhi kesuksesan karir tanpa menjadi variabel mediasi dalam penelitian ini.

\section{PENUTUP}

\section{Kesimpulan}

Berdasarkan penelitian dan pembahasan yang telah dijelaskan maka dapat ditarik kesimpulan bahwa perilaku inovatif berpengaruh positif dan signifikan terhadap kesuksesan karir. Hal tersebut menunjukan bahwa semakin tinggi perilaku inovatif maka akan meningkatkan kesuksesan karir karyawan. Perilaku inovatif berpengaruh positif dan signifikan terhadap self-efficacy. Hal ini menunjukan bahwa semakin tinggi perilaku inovatif maka akan semakin tinggi pula selfefficacy yang dimiliki oleh karyawan. Self-efficacy berpengaruh positif dan signifikan terhadap kesuksesan karir. Artinya semakin tinggi selfefficacy dalam diri karyawan maka akan meningkatkan kesuksesan karir karyawan. Selfefficacy tidak mampu memediasi pengaruh perilaku inovatif terhadap kesuksesan karir karyawan PT Bank Pembangunan Daerah Jawa Timur Tbk Kantor Pusat Surabaya. Artinya selfefficacy mampu berdiri sendiri manjadi variabel yang mempengaruhi kesuksesan karir tanda harus memediasi.

\section{Keterbatasan dan Rekomendasi untuk Penelitian Selanjutnya}

Penelitian ini hanya meneliti variabel perilaku inovatif, self-efficacy, dan kesuksesan karir. Hasil R-Square menunjukan bahwa perilaku inovatif hanya mampu menjelaskan self-efficacy sebesar $14 \%$ dan perilaku inovatif hanya mampu menjelaskan kesuksesan karir sebesar sebesar $40 \%$. Rekomendasi untuk penelitian selanjutnya yaitu dapat menggunakan variabel lain yang mampu menjelaskan self-efficacy dan kesuksesan karir lebih besar dari variabel perilaku inovatif.

\section{DAFTAR PUSTAKA}

Abele, A. E., \& Spurk, D. 2009. The Longitudinal Impact of Self-Efficacy and Career Goals on Objective and Subjective Career Success. Journal of Vocational Behavior, 74(1), 5362.

Aime, F., Dyne, L. Van, \& Petrenko, O. V. 2011. Role Innovation Through Employee Social Networks: The Embedded Nature of Roles and Their Effect on Job Satisfaction and Career Success. Organizational Psychology Review, 4(1), 339-361.

Azizah, S. N., \& Ma'rifah, D. 2017. Motivasi Usaha Sebagai Mediator Hubungan antara Perilaku Inovatif dan Kreativitas Terhadap Keberhasilan Pengusaha Batik Tulis di Kabupaten Kebumen. Sustainable Competitive Advantage, 7, 603-615.

Bandura, A. 1978. Self-Efficacy: Toward a Unifying Theory of Behavioral Change. Psychological Review, 1, 139-161.

Bandura, A. 1998. Self-Efficacy. Encyclopedia of Mental Health, 4, 71-81.

Brown, S. P., Jones, E., \& Leigh, T. W. 2005. The Attenuating Effect of Role Overload on Relationships Linking Self-Efficacy and Goal Level to Work Performance. Journal of Applied Psychology, 90(5), 972-979.

Chasanah, N. 2008. Analisis Pengaruh Empowerment, Self-Efficacy dan Budaya Organisasi Terhadap Kepuasan Kerja dalam Meningkatkan Kinerja. Tesis.

Chughtai, A. 2018. Authentic Leadership , Career Self-Efficacy and Career Success : A CrossSectional Study. Career Development International, 23(6/7), 595-607.

De Jong, J. P. J., \& Hartog, D. N. Den. 2007. How Leaders Influence Employees Innovative Behaviour. European Journal of Innovation Management, 10(1), 41-64. Fida, R., Laschinger, H. K. S., \& Leiter, M. P. 2016. The Protective Role of Self-Efficacy Against Workplace Incivility and Burnout in Nursing: A Time-Lagged Study. Health Care Management Review, 1-9.

Ghozali, I. 2014. Structural Equation Modeling, Metode Alternatif dengan Partial Least Square (PLS) (4th ed.). Semarang: Badan 
Penerbit Universitas Diponegoro.

Grosser, T. J., Venkataramani, V., \& Labianca, G. J. 2017. An Alter-Centric Perspective on Employee Innovation : The Importance of Alters' Creative Self-Efficacy and Network Structure. Journal of Applied Psychology.

Hall, P. 2000. Creative Cities and Economic Development. Urban Studies, 37(4), 639649.

Hirschi, A., \& Jaensch, V. K. (2015). Narcissism and Career Success : Occupational SelfEfficacy and Career Engagement as Mediators. Personality and Individual Differences, 77, 205-208.

Li, Z., You, L., Lin, H., \& Chan, S. W. 2013. The Career Success Scale in Nursing : Psychometric Evidence to Support The Chinese Version. Journal of Advanced Nursing, 70(5r), 1194-1203.

LinkedIn. 2014. Hasil Survei LinkedIn Tingkat Kepuasan Kerja. Retrieved February 3, 2019, from http://www.theprtalk.com/ newsroom/hasil-survei-linkedin-tingkatkepuasan-kerja

Liu, J., Yang, J., Yang, Y., \& Liu, Y. 2015. The Relationships Among Perceived Organizational Support, Intention to Remain , Career Success and Self-Esteem in Chinese Male Nurses. International Journal of Nursing Sciences, 1-5.

Muluk, H., \& Etikariena, A. 2014. Hubungan antara Memori Organisasi dan Perilaku Inovatif Karyawan. Hubs-Asia, 18(2), 77-88.

Ng, T. W. H., Eby, L. T., Sorensen, K. L., \& Feldman, D. C. 2005. Predictors of Objective and Subjective Career Success: A MetaAnalysis. Personnel Psychology, 58, 367408.

Peiperl, M., Arthur, M., \& Goffee, R. (2001). Career Frontiers: New Conceptions of Working Lives. Johnson Graduate School of Management, 46(3), 563-566.

Runhaar, P. ., Sanders, K., \& Yang, H. 2013. Promoting Teachers' Innovative Behaviour: The roles of Interdependence, Occupational Self-Efficacy and Learning Goal Orientation, $1-13$.

Schwarzer, R., Boehmer, S., Luszczynska, A., Mohamed, N. E., \& Knoll, N. 2005. Dispositional Self-Efficacy as a Personal Resource Factor in Coping After Surgery. Personality and Individual Differences, 39,
$807-818$.

Scott, S. G., \& Bruce, R. A. 1994. Determinants of Innovative Behavior: A Path Model of Individual Innovation in The Workplace. The Academy of Management Journal, 37(3), 580-607.

Seibert, S. E., Kraimer, M. L., Liden, R. C., Seibert, S. E., \& Kraimer, M. L. 2001. A Social Capital Theory of Career Success. The Academy of Management Journal, 44(2), 219-237.

Spurk, D., \& Abele, A. E. 2014. Synchronous and Time-Lagged Effects between Occupational Self-Efficacy and Objective and Subjective Career Success : Findings from a FourWave and 9-Year Longitudinal Study. Journal of Vocational Behavior, 84(2), 119132. https://doi.org/10.1016/j.jvb.2013.12.002

Sugiyono. 2018. Metode Penelitian Kuantitatif, Kualitatif, dan R\&D. Bandung: CV Alfabeta.

Sura, K., \& Hadi, C. 2017. Hubungan Antara Perilaku Inovatif dan Self-Efficacy Penyiar Radio di RRI Surabaya. Jurnal Psikologi Industri Dan Organisasi.

Tohardi, A. 2002. Pemahaman Praktis Manajemen Sumber Daya Manusia. Bandung: Universitas Tanjung Pura.

Turban, D. B., Moake, T. R., Wu, S. Y., \& Cheung, Y. H. 2016. Linking Extroversion and Proactive Personality to Career Success : The Role of Mentoring Received and Knowledge. Journal of Career Development, 1-14.

Woods, S. A., Mustafa, M. J., Anderson, N., \& Sayer, B. 2018. Innovative Work Behavior and Personality Traits Examining The Moderating Effects of Organizational Tenure. Journal of Managerial Psychology, 33(1), 29-42.

Zacher, H. 2014. Career Adaptability Predicts Subjective Career Success Above and Beyond Personality Traits and Core Self-Evaluations. Journal of Vocational Behavior, 84(1), 21-30. 